\title{
Vulnerability to air embolism of three European oak species (Quercus petraea (Matt) Liebl, $Q$ pubescens Willd, $Q$ robur $L$ )
}

\author{
H Cochard *, N Bréda, A Granier, G Aussenac \\ Laboratoire d'Écophysiologie Forestière, Station de Sylviculture et Production \\ INRA, Centre de Nancy, F-54280 Champenoux, France
}

(Received 14 October 1991; accepted 14 January 1992)

\begin{abstract}
Summary - The vulnerability to water-stress induced cavitation and the petiole leaf specific conductivity (LSC) have been studied on excised branches of Quercus petraea, $Q$ pubescens, $Q$ robur and $Q$ rubra. Seasonal evolution of xylem embolism in the petioles and twigs of mature $Q$ petraea has been followed together with increasing soil water deficit. Field experiments showed that $Q$ petraea suffered from embolism damage in both petioles and twigs after heavy drought. Large differences in terms of vulnerability to cavitation and LSC have been found between species. $Q$ pubescens presented the highest LSC and the lowest vulnerability together with $Q$ petraea. $Q$ robur was found to be more vulnerable than $Q$ petraea although with comparable LSC. $Q$ rubra was the most vulnerable species and exhibited the lowest LSC. It was concluded that these species could be classified according to how their hydraulic mechanism is conceived to resist cavitation events : $Q$ pubescens was the most resistant followed in order by $Q$ petraea, $Q$ robur, and $Q$ rubra. Results are discussed in terms of plant segmentation and drought resistance.
\end{abstract}

Quercus spp = oaks / xylem cavitation / hydraulic architecture / hydraulic conductivity / drought resistance

Résumé - Vulnérabilité à l'embolie de trois espèces de chênes européens (Quercus petraea (Matt) Liebl, $Q$ pubescens Willd, $Q$ robur $L$ ). La vulnérabilité à la cavitation induite par stress hydrique et la conductivité spécifique foliaire (LSC) ont été étudiées sur des branches excisées de $Q$ petraea, $Q$ pubescens, $Q$ robur et $Q$ rubra. L'évolution saisonnière de l'embolie xylémienne des pétioles et des tiges de $\mathrm{Q}$ petraea adultes a été suivie au cours de l'établissement d'une sécheresse édaphique. L'expérimentation en conditions naturelles a montré que l'on pouvait induire de l'embolie dans les pétioles et les tiges de Q petraea après une sécheresse. De grandes différences en terme de vulnérabilité à la cavitation et de LSC ont été trouvées entre les espèces. Q pubescens présente la plus grande $L S C$ et, avec $Q$ petraea, la plus faible vulnérabilité, $Q$ robur est plus vulnérable que $Q$ petraea bien que sa $L S C$ soit comparable. Q rubra est l'espèce la plus vulnérable et celle qui montre la plus faible LSC. A la suite de ces résultats nous arrivons à la conclusion que ces espèces peuvent être classées selon leur résistance à la cavitation : $Q$ pubescens est le plus résistant suivi

* Correspondence and reprints 
dans l'ordre par $Q$ petraea, $Q$ robur et $Q$ rubra. Ces résultats sont discutés en termes de segmentation de l'appareil conducteur et de résistance à la sécheresse.

Quercus spp = chênes / embolie / cavitation / architecture hydraulique / conductivité hydraulique / résistance à la sécheresse

\section{INTRODUCTION}

After the exceptional drought that occurred in France in 1976, significant dieback symptoms were noticed in mid European oak trees. Preliminary observations showed that, in mixed stands, only one species, Quercus robur, was declining (Becker and Lévy, 1982) whereas the closely related species $Q$ petraea was more drought-resistant. Another related species, $Q$ pubescens, is mostly found in Southern Europe where severe drought develops every summer. The subgenus Lepidobalanus section robur (Krüssmann, 1978), which includes all the above species, thus exhibits very different responses to water stress. Since 1976, a number of ecological studies have been undertaken to determine the mechanisms of this drought related dieback (eg Guillaumin et al, 1983; Dreyer et al, 1990; Vivin et al, unpublished data), but no striking differences have yet been found between $Q$ robur and $Q$ petraea that could explain their ability to support or not support water stress.

The vulnerability of the xylem to cavitation and air embolism has been examined in a number of recent studies (eg Tyree and Sperry, 1989; Sperry and Tyree, 1991). Large differences in susceptibility to cavitation and hydraulic architecture have been found between species. In most of these species, embolism was likely to develop during severe drought. The main consequence of embolism formation in the conducting tissue is an increase of resistance to water flow along the sap pathway.
The water relations of the whole tree might thus be seriously affected and crown desiccation be predictable. The vulnerability of the European oak species to cavitation is undocumented and the possible implication of xylem dysfunctions due to air embolism in oak decline is a feasible hypothesis.

In order to investigate this hypothesis we compared the susceptibility to droughtinduced air embolism and the hydraulic properties of $Q$ petraea, $Q$ pubescens and $Q$ robur. Vulnerability curves (VC), the relations between water potential and the extent of embolism in the xylem, were obtained by drying out excised branches using 2 different techniques. We also compared these laboratory experiments with the natural development of embolism in mature $Q$ petraea trees submitted to artificial water shortage.

\section{MATERIALS AND METHODS}

\section{Vulnerability curves}

For each species, VCs were obtained from 2-4year-old branches excised from mature trees growing on open areas at the INRA station, near Nancy, eastern France. $Q$ robur and $Q$ petraea were 2 native trees, and $Q$ pubescens was a planted specimen originating from southern France. Some experiments were also conducted on a planted $Q$ rubra. Branches were collected in the morning with pruning on the southern part of the trees, they were then recut under water and rehydrated for about 1 hour. Two methods were used to induce embolism in the xylem: 
- for each species, several branches were first dehydrated using the traditional method by drying them on a laboratory bench over a variable period of time. Increasingly stressed branches were thus obtained, with water potentials ranging from -2 to $-5 \mathrm{MPa}$;

- other branches excised from the same trees were enclosed in a large pressure chamber, pressurized to 2-4 MPa until the pressure equilibria of the samples were obtained. At this point the pressure was slowly released down to atmospheric pressure. With both techniques the branches were then kept overnight in a plastic bag in order to induce pressure equilibrium and air diffusion into the cavitated vessels. Before cutting segments for embolism measurement, samples were soaked undel water for at least half an hour in order to release xylem tension.

Embolism was estimated via its effect on loss of hydraulic conductivity (Sperry et al, 1988). Embolism was evaluated in the terminal part of the current-year twigs and in the petioles. Embolism of the samples dehydrated in the ressure chamber was analyzed only in the petioles. On each branch, usually 15 samples (8 leaves and 7 twigs) 2-3 cm long were cut under water with a razor blade. When the petioles were less than $2 \mathrm{~cm}$ long, the leat blades was detached, the samples thus containing part of the mid rib. Hydraulic conductivity was measured by perfusing samples with a $65-\mathrm{cm}$ head of degassed distilled water containing $0.1 \%$ of $\mathrm{HCl}(\mathrm{pH}=2)$. Conductivity was restored by repeated flushes of perfusion solution pressurized to $0.1 \mathrm{MPa}$. A 20-min flush was usually sufficient to fully resaturate the samples, but a second flush was performed to confirm the previous value and to detect any plugging of the xylem during the flush. The leaf area was measured for $Q$ petraea and $Q$ robur, and occasionally for $Q$ pubescens and Q rubra.

\section{Natural development of embolism}

Field experiments have been conducted in a 30year old stand of Quercus petraea in the forest of Champenoux near Nancy, eastern France. Average height of the stand was $15 \mathrm{~m}$ in 1990 and estimated leaf area index 6 (Breda et al, 1992). Two representative plots of 4 trees each were selected for measurements. One of the plots was maintained in a well hydrated condition by successive irrigation throughout the summer. The second was submitted to a water shortage by digging a 1.2-m deep ditch around the plot and covering it with a watertight roof. In both plots, a $15-\mathrm{m}$ scaffolding enabled direct sampling from the crown of the trees. Air temperature at the crown level was measured continuously with a platinum probe. On a weekly basis, midday leaf water potential of all the trees of the 2 treatments was measured with a pressure chamber. All the measurements were performed on sunny days. From the beginning of June 1990 to late December 1990, 1-3-year-old branches were periodically cut from the crown of the same trees with pruning shears. One-yearold branches were immersed in water before cutting. Preliminary observations showed that no significant embolism was induced in the petioles and in the apical parts of the twigs by cutting the samples in this manner. Samples cut early in the morning were brought to the laboratory in air-tight bags and allowed $0.5 \mathrm{~h}$ to rehydrate, soaked under water before measurements were taken. On each branch, embolism was measured in 10 randomly chosen leaves, and in all the terminal parts of the current year twigs (1-10 samples; average 5). Embolism was measured as described for vulnerability curves. A VC was also established on the petioles of a control tree by means of the pressure chamber dehydration technique.

\section{RESULTS}

\section{Vulnerability curves}

Within-tree (twigs versus petioles) variations of vulnerability to embolism are shown in figure 1 for the 3 studied oak species. We have also replotted on the same graph data obtained on $Q$ rubra by Cochard and Tyree (1990). Although VCs of petioles and twigs were similar, at low water potentials embolism was significantly more developed in the petioles than in the twigs. In figure 2 we plotted, on the same graph, the VCs of the 4 species for both 


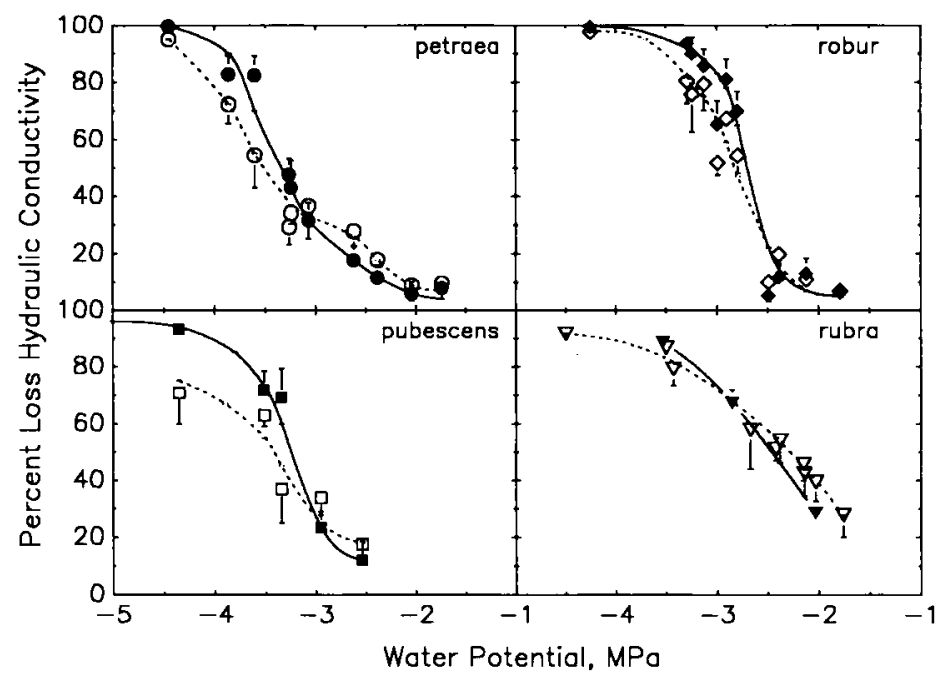

Fig 1. Vulnerability to cavitation of petioles (closed symbols) compared to 1-year-old twigs (open symbols) of 4 species of oak. Excised branches were dried out on a laboratory bench. The x-axis is the minimum water potential reached by each branch. Embolism was estimated via its effect on hydraulic conductivity. Errors bars are $95 \%$ confidence intervals $(n=7-10)$.

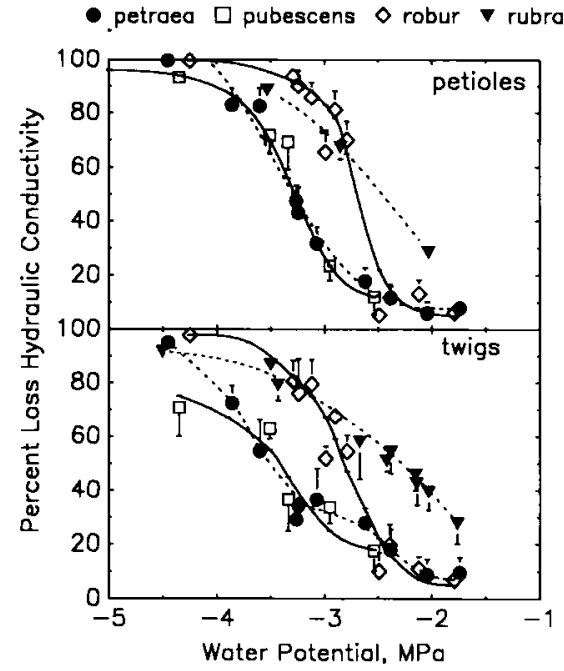

Fig 2. Between species variations of petioles (upper) and twigs (lower) vulnerability to cavitation. Same data as in figure 1. Closed circles: $Q$ petraea, open squares : $Q$ pubescens, open diamonds : $Q$ robur, closed inverted triangles : Qrubra. petioles and twigs. Significant differences were found between species. $Q$ rubra was the most vulnerable species: embolism developed when water potential was less than $-1.5 \mathrm{MPa}$ and $50 \%$ loss of conductivity was noted for potentials around -2.4 $\mathrm{MPa}$. The 3 European species exhibited a similar water potential threshold needed to induce significant loss of hydraulic conductivity (around $-2.5 \mathrm{MPa}$ ) but the development of embolism was much greater in $Q$ robur than in the 2 other species. We noted $50 \%$ loss of conductivity at a water potential around $-2.7 \mathrm{MPa}$ for $Q$ robur as compared to $-3.3 \mathrm{MPa}$ for the 2 other species. VCs of $Q$ petraea and $Q$ pubescens were similar.

The comparison of VCs of petioles showed that the 2 methods used to dehydrate samples (air versus pressure chamber) were not significantly different (fig 3). This also pertained to $Q$ rubra although the 


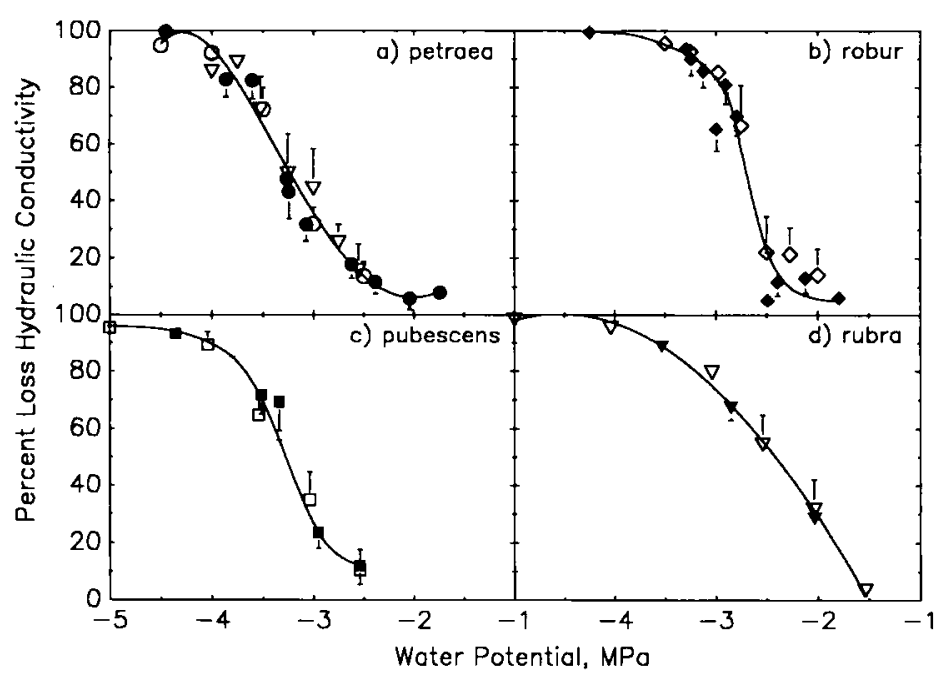

Fig 3. Vulnerability curves obtained on petioles by air (closed symbols) compared to pressure chamber (open symbols) dehydration (see text for details). Experiments were conducted on the same tree for each species except for $Q$ rubra where air-dried branches were collected from trees native to Northeastern America, and a pressure-chamber dehydrated branch from a planted tree in Eastern France. In figure $3 a$ the vulnerability curve of a tree from the forest stand of Champenoux is also plotted (open circles).

2 curves were respectively obtained on North American and European grown trees for air and pressure-chamber dehydrated branches.

The relationship between the leaf area and the hydraulic conductivity of the petioles (leaf specific conductivity, LSC) is shown in figure 4. Quercus rubra exhibited the lowest LSC and $Q$ pubescens the highest. $Q$ robur and $Q$ petraea were similar. For any given leaf area, the LSC of $Q$ pubescens petioles was approximately 2 times higher than the LSC of $Q$ petraea or $Q$ robur and 5 times higher than $Q$ rubra.

\section{Natural development of embolism in $\mathrm{Q}$ petraea}

Figure 5 shows the seasonal progression of minimum water potential of $Q$ petraea

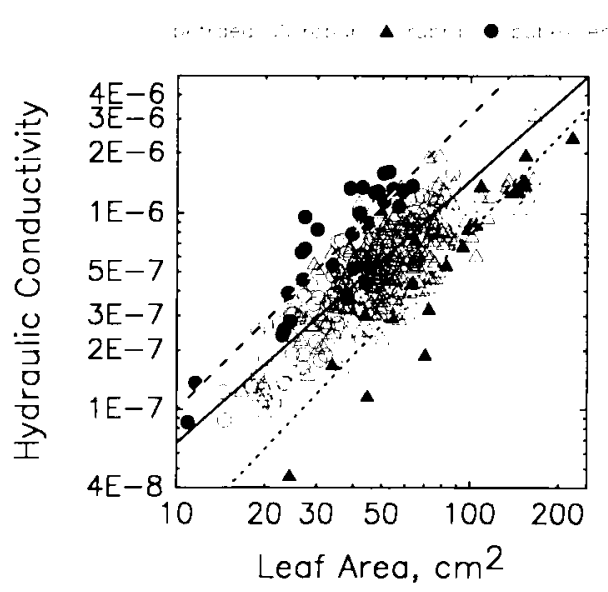

Fig 4. Hydraulic conductivity (kg m.s $\mathrm{s}^{-1} \mathrm{MPa}^{-1}$ ) of petioles versus leaf area in the petiole of 4 species of oak. Scales are logarithmic, lines are linear regressions through log values: solid line $=Q$ petraea and $Q$ robur; dashed line $=Q p u$ bescens; dotted line $=Q$ rubra . 


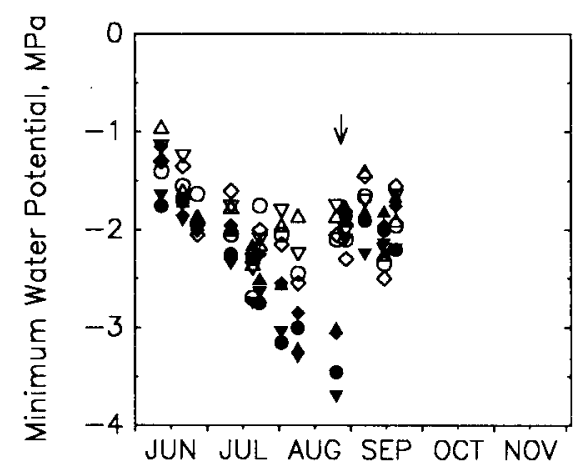

Fig 5. Seasonal progression of minimum water potential of control (open symbols) and water stressed trees (filled symbols). Different trees within each treatment are represented by different symbols. The arrow indicates rehydration following the dry treatment.

for the control and the dry treatments. Minimum water potentials of the control trees did not fall below $-2.5 \mathrm{MPa}$ at any time. Since the onset of the drought period (when the plot was covered with the roof) and up till rehydration (23/8/1990) the minimum water potential of the stressed trees kept decreasing down to a minimum of $-3.4 \mathrm{MPa}$. After rehydration following the dry treatment, water potentials of both plots no longer differed.

Seasonal progression of embolism in the petioles and the twigs for both treatments is shown in figure 6 . From the beginning of June to late October, we found no significant increase in the percent loss of hydraulic conductivity in the control trees (stable value around 10\%). Embolism in the dry treatment developed significantly at the end of July and reached a maximum just before rehydration. There was a large variability in terms of percent loss of conductivity within the trees of the dry plot. One tree seemed more affected by the water shortage than the others. The

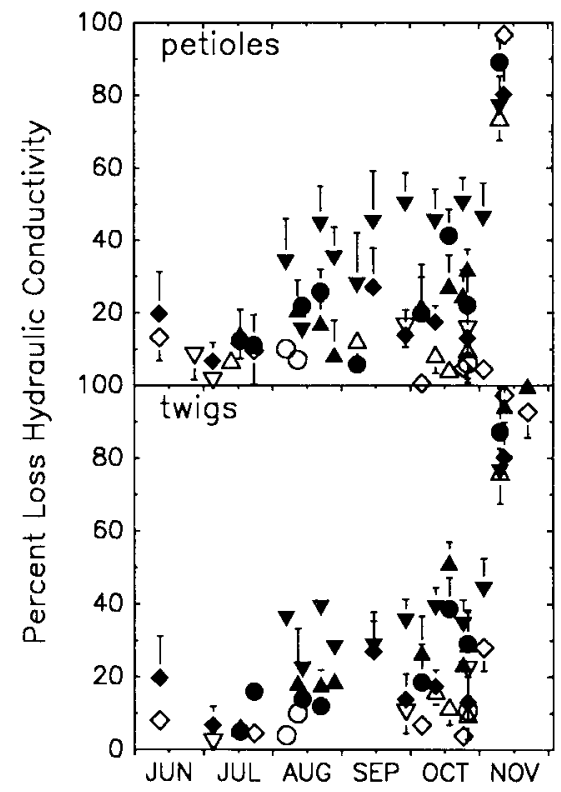

Fig 6. Seasonal progression of xylem embolism in petioles (upper section) and 1-year old twigs (lower section) for both control (open symbols) and water stressed trees (filled symbols). Different trees are represented by the same symbols as in figure 5.

loss of conductivity was around $50 \%$ for this tree as compared to $15-30 \%$ for the 3 others. After rehydration, embolism remained constant for all stressed trees. Loss of hydraulic conductivity for the same tree was usually slightly lower in twigs than in the petioles but followed the same trend throughout the seasons. Embolism in all trees, and in all parts of these trees, increased drastically at the beginning of November following the first frost $\left(-2.6^{\circ} \mathrm{C}\right)$ recorded in the stand. This frost-induced embolism in $Q$ petraea is comparable to what has been observed by Cochard and Tyree (1990) in north-eastern America in $Q$ rubra and $Q$ alba. 
The VC of one of these trees is shown in figure $3 \mathrm{a}$ (open circle). No differences were found between this forest-standgrown tree and the open-area-grown tree.

\section{DISCUSSION}

Vulnerability curves obtained with oak branches dehydrated in a pressure chamber were very similar to those acquired with twigs dehydrated on a laboratory bench. The same agreement was found in walnut petioles (Juglans regia) (Cochard et al, unpublished data), on 2-4 year-old conifer branches (Abies alba) (Cochard, 1992), and in the current year twigs of 2 diffuse-porous species (Salix alba and Populus deltoides; Cochard et al 1992). Two hypotheses might be considered regarding the mechanisms of embolism formation in pressure-chamber dehydrated branches. Air might be sucked inside a vessel during the decompression phase while tension develops in the xylem, or air might be pushed inside the vessels while the pneumatic pressure rises. The relative pressures that develop at the water-air meniscus are in both cases of the same order of magnitude and would have the same consequences on embolism induction.

Zimmermann (1983) introduced the principle of plant segmentation stating that embolism should develop first in the terminal part of the trees (ie, leaves and small branches), thus preserving the bole and the main branches from embolism damage. This segmentation is determined by the hydraulic architecture of the tree, ie by the leaf specific conductivity of xylem, which determines the water potential drop along the sap pathway, and also by the vulnerability of the different organs (Tyree and Ewers, 1991). Petioles of Quercus petraea are slighly more vulnerable than its twigs and are submitted to lower water potential so we might expect the petioles to cavitate first. An experimental confirmation of this segmentation can only be obtained on intact drying trees, because the water potential drop along the conducting tissue will not be modified. Results from the field experiment have confirmed that embolism is more developed in petioles than in twigs, but we must conclude that the segmentation of $Q$ petraea was not sufficient to preserve the twigs from any embolism damage.

Although the vulnerability of species to air embolism is only starting to be documented, oak species might be qualified as rather "resistant" species as compared to some pioneer trees like Salix alba (Cochard et al, unpublished data), Populus tremuloides (Tyree et al, 1992), or Schefflera morototoni (Tyree et al, 1991) whose vessels cavitate between -1 and $-2 \mathrm{MPa}$. VCs are usually obtained from one single tree so we might question their representativeness. In this study we found that $2 Q$ petraea trees, one growing in a forest stand, the other in an open area, exhibited very comparable VCs. Furthermore, the VCs of $2 Q$ rubra trees from 2 different continents were also similar. In the light of these results, it seems that trees growing in climatically comparable areas exhibit only little variation in VCs. But it is conceivable that species with large amplitude of ecological habitats (mesic to xeric) also manifest intraspecific differences in their VCs. The relations between the hydraulic architecture of a species and its growing conditions deserve further study.

It has recently been proposed that the risk of xylem dysfunction due to cavitation events may determine the stomatal behavior of a plant and its ability to resist drought (Jones and Sutherland, 1991; Tyree and Ewers, 1991). The limitation of xylem embolism in a plant can both be physiological 
(low transpiration rate due to stomatal closure or leaf fall) or hydraulic (low vulnerability, high LSC) or more likely a combination of these features. Our results on oak species have shown significant variations of vulnerability to cavitation and LSC between species. The LSC was measured in this study only in the petioles, so only provisional conclusions can be advanced. But it has been proved (Tyree, 1988; Tyree et al, 1991) that in woody plants the highest drop in water potential was found in the terminal part of the vascular system (ie, small branches and petioles). Consequently the hydraulic design of the petioles might be a decisive feature in characterizing the hydraulic architecture of a broadleaved tree. Because of its high LSC and its low vulnerability $Q$ pubescens minimizes the risk of cavitation events in its petioles. Conversely, $Q$ rubra is the species that is the most likely to develop embolism in its xylem. Cochard and Tyree (1990) found that the native level of embolism was around $25 \%$ in the twigs of this species even in the absence of drought. $Q$ robur and $Q$ petraea have the same LSC but $Q$ robur is more vulnerable; this species might thus be more subject to cavitation events.

Our results have shown that the European species known for being "droughtresistant" are also those whose hydraulic architecture seems to minimize the risk of cavitation events in the vessels. But we still do not have experimental confirmation under field conditions that droughtresistant species are cavitation-resistant. We also do not know how embolism affects the physiology of the tree and if can be directly responsible for mortality. This is a relevant problem for oak and other ringporous species whose vessels naturally become embolised during the winter. Furthermore, our results have shown that among the species, studied, $Q$ rubra pos- sessed less advantageous architecture in terms of cavitation-avoidance, although this species was rather drought-resistant (Vivin et al, 1992, unpublished data). We conclude that cavitation resistance is only part of the strategy developed by this species to survive periods of drought. In the light of these preliminay results, it is considered that the hydraulic architecture and the vulnerability to cavitation of trees, and oak particularly, deserve further study and might have important implications in their ability to withstand drought.

\section{ACKNOWLEDGMENTS}

This study was partly financed by the Water Stress, Xylem Dysfunction and Dieback Mechanisms in European Oaks research program (EEC DG XII, STEP CT90-0050-C). We thank B Clerc, $P$ Gross, and $F$ Willm for technical assistance at the Champenoux site. We thank MT Tyree for helpful criticism of the first draft of this manuscript.

\section{REFERENCES}

Becker M, Lévy G (1982) Le dépérissement du chêne en forêt du Tronçais. Les causes écologiques. Ann Sci For 36, 439-444

Bréda N, Cochard H, Dreyer E, Granier A, Aussenac $G$ (1992) Water transport in oak trees submitted to drought: hydraulic conductivity and xylem dysfunctions. Ann Sci For 49 (in press)

Cochard H, Tyree MT (1990) Xylem dysfunction in Quercus: vessel sizes, tyloses, cavitation and seasonal changes in embolism. Tree Physiol 6, 393-407

Cochard H (1992) Vulnerability of several conifers to air embolism. Tree Physiol (in press)

Cochard H, Cruiziat P, Tyree MT (1992) Use of positive pressures to establish vulnerability curves: further support for the air-seeding hypothesis and possible problems for pressurevolume analysis. Plant Physiol (in press) 
Dreyer E, Bousquet F, Ducrey M (1990) Use of pressure volume curves in water relation analysis on woody shoots: influence of rehydration and comparison of four European oak species. Ann Sci For 47, 285-297

Guillaumin JJ, Bernard C, Delatour C, Belgrand $M$ (1983) Le dépérissement du chêne à Tronçais : pathologie racinaire. Rev For Fr 35, 415-424

Jones HG, Sutherland RA (1991) Stomatal control of xylem embolism. Plant Cell Er.viron 14, 607-612

Krüssmann G (1978) Handbuch der Laubgehölze. P Parey-Verlag, Hamburg

Sperry JS, Donnelly JR, Tyree MT (1988) A method for measuring hydraulic conductivity and embolism in xylem. Plant Cell Environ $11,35-40$

Sperry JS, Tyree MT (1990) Water-stressinduced xylem embolism in three species of conifers. Plant Cell Environ 13, 427-436

Tyree MT (1988) A dynamic model for water flow in a single tree: evidence that models must account for hydraulic architecture. Tree Physiol 4, 195-217

Tyree MT, Sperry JS (1989) Vulnerability of xylem to cavitation and embolism. Annu Rev Plant Physiol Mol Biol 40, 19-38

Tyree MT, Ewers FK (1991) The hydraulic architecture of trees and other woody plants. New Phytol (in press)

Tyree MT, Snyderman DA, Machado JL (1991) Water relations and hydraulic architecture of a tropical tree (Schefflera morototoni): data, models and a comparison to two temperate species (Acer saccharum and Thuja occidentalis). Plant Physiol (in press)

Tyree MT, Alexander J, Machado JL (1992) Loss of hydraulic conductivity due to water stress in intact juveniles of Quercus rubra and Populus deltoides. Tree Physiol (in press)

Zimmermann MH (1983) Xylem Structure and the Ascent of Sap. Springer Verlag, Berlin, $143 p$ 